\title{
Mythic Revisionism: Women Poets and Philosophers in Italy Today
}

Does it make sense to talk about "women poets" rather than "poets" tout court? There are strong disagreements on this issue and women poets are often the first ones to tell you that true poetry is gender blind. I want to outline the current debate on the notion of sexual difference in order to reconsider "écriture feminine," in terms which will hopefully be neither reductive nor metaphysical. Two Italian philosophers whose work I find challenging and useful have influenced my thinking on this subject: Aldo Gargani and Adriana Cavarero. In particular, a 1984 text by Gargani entitled "La voce femminile," and a recent book by Cavarero entitled Nonostante Platone will be a focal point of the present essay. In outlining a possible strategy for reading contemporary Italian women poets, I will examine "mythic revisionism" as a practice of poetic writing that many though certainly not all - women poets share; a practice that may amount to a specifically, though not exclusively, feminine aesthetic pursuit.

This strategy of reading women poets in terms of "mythic revisionism" has a threefold goal: a) to contribute to the present inquiry among feminist critics into the specificity of women's writing; b) to call attention to the complex relationship between Italian women poets and the (mostly) male canon in both stylistic and thematic terms; c) to see how, through its probing of some of the fundamental mythologies of western patriarchal culture, the work of women poets acquires a philosophical depth and symbolic import that make it one of the fundamental discourses through which humanity (not just women) is rethinking itself at the end of a millennium dominated by patriarchy and its symbolic order.

I will refer mainly to the work of contemporary Italian women poets Rossana Ombres, Maria Luisa Spaziani, Rosita Copioli, and Amelia Rosselli, as well as to the philosophical work of Cavarero and Luisa Muraro. My readings of their texts aim to demonstrate what the stakes involved are, for Italian women poets and for the canon of modern Italian poetry, as well as for certain mythologies of western patriarchal thought, in the critical-creative practice of mythic revisionism. Why mix a discussion of philosophical texts with the analysis of poetic texts? It is my belief that the tasks of poetry and philosophy are never separated, but proceed hand in hand as elaborations of and responses to the logic of the symbolic order. As Cavarero's and others' critiques of Plato show, both discourses help to shape and perpetuate certain mythic constructions of gender and sexual difference entrenched in the practices of and reflections on human existence throughout history. They shape our intelligence, our sensibility, and our lives. ${ }^{1}$ 
First, then, does it make sense to speak of "women poets"? The Italian language itself, like French and English, seems to reject this concept. The word poeta is used for both women and men. There is, as Xavière Gauthier has pointed out in a famous piece, in all three languages the word "poetess," but it is a "ridiculous word ... synonymous with foolish innocence . . . or old-lady respectability. There are, however, women who write. Is their writing different from men's? In what ways does their writing call attention to the fact that they are women?" (160). The answer for many Italian women writers is: in no way. Giulia Niccolai, for example, gives an implictly negative answer to the question when she says, provocatively: "Propongo di usare dei testi come cavia: testi maschili e testi femminili mescolati all'insaputa del pubblico. Il quale dovrà indovinare quali sono gli scritti di origine maschile e quali sono gli scritti di origine femminile, indipendentemente dall'argomento" (Frabotta 161). Maria Luisa Spaziani - an altogether different poet — is also unwilling to accept the label "woman poet." Answering the same question, she asserts that "la singola voce di un poeta donna valeva e vale di per sé, per una sua unicità sensibile e morale, la stessa che differenzia i libri importanti scritti da uomini" (143).

Why should Italian women poets be so reluctant to accept this label, or to formulate a link between writing and gender? One answer lies in the way the word "feminine" has traditionally been used, with a host of connotations that women poets would understandably like to do without. Maria Luisa Spaziani is a case in point. Her voice has been called "feminine" because it is "lyrical," "singing," "graceful" and "melodious," and because her poetry reappropriates the dimension of the private and the experiential with a renewed ability to communicate them through language. ${ }^{2}$ The stereotype of women's poetry as effusive, sentimental and autobiographical is implicit here, a stereotype which has an uncanny ability to creep into the discourse of even well-meaning critics when they discuss poetry by women. ${ }^{3}$ Another facet of this stereotype is the attribution to women's poetry of certain supposedly feminine qualities such as intuition and sensitivity. We need to "free" the word "feminine" from these stereotypical associations and explore its possible meanings in relation to poetry written by both men and women. What we need is, in effect, a new way of thinking about sexual difference and its impact on writing.

In her response to the same question, Amelia Rosselli gives a more thoughtful, if tentative, view of the question of writing and gender difference. She says that although in her work she has never felt compelled to specify or refer to her feminine identity as an author, there is a strong and voluntary link between her writing and her femininity, particularly visible in her early long poem, "La libellula," where she refers to the arduous psycho-social condition of women by picking up a theme first found in Rimbaud. But besides thematic concerns, is there a specifically linguistic difference in women's writing? Rosselli argues that this may not be as far-fetched as it appears: "Che esista una differenziazione linguistica femminile è da sospettarsi, sia essa da 'quarto mondo' o biologica, 
addirittura in origine, anche se rimane da studiare in campo sperimentale, secondo me. Che la donna imiti l'uomo nello scrivere è ovvio, e forse un suo rintracciare forme artistiche sue originarie o perfino chimicamente più sue, resta problema aperto. Ma se la donna ne è conscia, il suo scrivere si fa davvero più laborioso!" (159-60). Feminity in writing by women, then, is not something that can be assumed, a biological or biographical given. It is rather a possibility, something to be uncovered or unveiled or, conversely, pursued and constructed.

Let's assume then, for the sake of discussion (although I realize my contention is far from proven) that it is legitimate to speak of "women poets" not because there are poets who incidentally happen to be women, but because something specific in their writing makes it different from men's. How does this difference become visible or readable? ${ }^{4}$ It is only because women writers subscribe for the most part to a "masculine" system of signification - as Gauthier argues - that "men and women seem to speak approximately the same language; in other words women find their 'place' within the linear, grammatical, linguistic system that orders the symbolic, the superego, the law. It is a system based entirely upon one fundamental signifier: the phallus" (162). The destabilization of this system of signification then, may itself be seen as a mark of the feminine in writing. It has been argued that a woman author like Marguerite Duras, who writes of a restless, shifting and mysterious interiority, is an example of "feminine writing" in that she refuses to translate this interiority into a "masculine," clarifying, authoritative - and authoritarian - psychology (Di Battista 288). Yet writing itself for Duras means to take on a masculine posture. "The woman who writes," she says in Les Parleuses, "disguises herself as a man." As writers, Duras feels, women are always clandestine: they exist, but almost in secret, as saboteurs and underground agents. Theirs is a kind of selfconscious mimicry and parody, or transgression through mimicry, of the institution of "male" authorship. Feminine writing as a specific discourse of femininity does not yet have a form: rather, it manifests itself only as deformation; it becomes audible or visible in the "holes in discourse, in the un-said, or in the nonsense" (Gauthier 163). It often appears as a kind of madness.

This way of describing feminine writing - interesting as it is - makes it look a lot like the poetic practice of experimentalism and the avant-garde, from Futurism on. And since the exponents of the avant-garde have mostly been men, we come to the paradox that feminine writing may after all belong - at least thus far - more to men than to women. This argument is not new; it is Julia Kristeva's. She claims that the subject experiences sexual difference not as a fixed opposition - man/woman - but as a process of differentiation. Only very recently have a few women writers produced work where the dissection of language reaches levels comparable to those of the real subverters of phallic dominance in discourse, Mallarmé, Lautréamont, Joyce and Artaud. Kristeva is not alone in this view of the relation between writing and gender difference. Even Hélène Cixous, in "The Laugh of the Medusa" (which is itself one of the 
first examples of self-conscious feminine writing and mythic revisionism), states that, with a few exceptions, there has not yet been any writing that inscribes femininity, that is, a writing which does not suscribe to a masculine economy. The few exceptions include Kleist and Genet, whom she places alongside Colette and Duras. For Cixous, feminine writing, then, is not necessarily the domain of women writers, though of course she wishes that it would increasingly become so. Instead, feminine writing is often the domain of poets - "rather than novelists, allies of representationalism. Because poetry involves gaining strength through the unconscious and because the unconscious . . . is the place where the repressed manages to survive: women, or as Hoffmann would say, fairies" (250).

To speak of women poets, therefore, does not necessarily mean to speak of feminine writing, and viceversa. There are some obvious problems with this position, first and foremost political. If feminine writing can be attributed to male writers, especially poets, it is all the easier to continue to ignore women poets, to continue to exclude them from symposia, anthologies, the literary canon. Therefore, while I am skeptical of positions such as Irigaray's, who argues the irreducibility of anatomical and physiological difference as a basis for gender difference in writing, I prefer to opt strategically for a compromise which allows me to pursue the question of gender difference in relation to writing and to read Italian women poets at the same time. This is dictated not by any firm hermeneutical faith, but rather by the specific historical circumstances of feminist theory and criticism on the one hand, and the problem, on the other, of the conspicuous glossing over of the presence, authority and importance of women poets in modern Italian literary culture.

A second reason for such a move is the hypothesis that although there might not appear to be any fundamental differences between the destabilizing rhetorical and stylistic strategies of the historical avant-gardes and what has been called "écriture féminine," this lack of difference may be due to a lack of serious scrutiny of texts - especially avant-garde texts - by women. ${ }^{5}$ While it may be (rather trivially) true, as Rita Felski remarks, that "linguistic playfulness and nonlinear syntax are in no sense unique or specific to women" (37), is it true that James Joyce's and Dorothy Richardson's experimentations with the novel form amount to the same thing, and that gender plays no role in the differences detectable between their styles? How can we even begin to address such a question when the study of Richardson - as of most experimental women writers (even Stein, not to mention Italian writers ) - is still in its infancy? Felski contends, as do other critics, that "the gender-specific qualities [of "écriture féminine"] can only be sought in [its] particular content, in representations of the female body or recent explorations of mother-daughter relationships for example, rather than in any stylistic features which can be designated as uniquely feminine" (38). This statement ought to give us pause. For how can we really go back to such a distinction between form and content, especially when we discuss poetry? Thematics make it easier to distinguish a male-authored from a female-authored 
text, true, but thematics are always imbricated with rhetoric, style, language. And language itself, as Patrizia Violi has shown, is far from being gender blind, but rather bears the semiotic traces of the sexed nature of the speaking subject (20911).

I prefer therefore to side with the philosophers Aldo Gargani and Adriana Cavarero. From Gargani I will borrow a provocative definition of "feminine voice," which I believe can contribute to discerning a common thread or ethical tendency in the work of some Italian women poets today. From Cavarero I will borrow (or steal) the notion of a feminine symbolic order, which will help me define what I have called the practice of mythic revisionism.

"La voce femminile (della lingua femminile scritta o parlata)," writes Gargani, "si caratterizza per un tono che è fondamentalmente quello dell'interrogazione. La lingua delle donne in linea di massima non costruisce sistemi, non avanza tesi, non tende nemmeno al possesso dei fatti; si lascia piuttosto definire mediante la differenza rispetto a tutti quegli atteggiamenti. Lo stile della voce femminile si estrinseca più nella forma della interrogazione, della domanda, che non in quello dell'affermazione. [. . . ] Non brama e non accetta il possesso che sui fatti rivendicano gli uomini, quel possesso dal quale si finisce per essere posseduti, perché avverte nel possesso lo sbarramento dell'intenzione, della volontà, del significato. [. . . ] Essa scopre al di là dei fatti, delle tesi e dei sistemi eretti dagli uomini lo spazio della contingenza, dell'intenzione, del senso [. . . e] un arbitrio originario. [. . .] L'eticità della voce femminile risplende nella chiamata che essa rappresenta nei confronti di tutti i segni, tracce, voci, che sono state dimenticate e disattese" (16). Gargani is one of the foremost Italian critics of western paradigms of rationality and metaphysics, whose "crisis" has led in turn to radical responses such as those of Gianni Vattimo and so-called "pensiero debole." Gargani's suggestion, therefore, that what he calls the "feminine voice" points in the direction of different modes of (non-patriarchal) thought is intended as a positive assessment of the alternate means the feminine voice offers for thinking and living beyond the crisis of (patriarchal) reason. Gargani points in particular to the work of Virginia Woolf and Ingeborg Bachmann as examples of feminine writing. Given the apparent stylistic disparity between these two writers, what are the qualities they share, what makes their voices feminine? "Ciò che costituisce la specificità della voce femminile tra scrittrici fra loro diverse,"writes Gargani, "è la tensione verso un senso che, di fronte alla resistenza eretta dalla verità notarile sottoscritta dagli uomini ordinariamente, fatalmente si estrinseca come richiamo, come strazio, come grido. In ogni caso si estrinseca come propensione alla descrizione, al passaggio da una condizione di verità alla condizione del senso di quella verità, anziché all'argomentazione sistematica paranoide che assolve al bisogno di affermazione e di possesso che spinge normalmente gli uomini" (16). The otherness of the feminine voice for Gargani resides in its ability to probe the past, to recall and scrutinize the obliterated and forgotten, and to perceive alternate senses behind and beyond the 
official history and truth by which patriarchy abides. I am interested in showing how this otherness ("alterità") of the feminine voice as defined by Gargani finds expression in the interrogation, undoing and tentative reshaping of certain key mythic moments or figures (especially but not exclusively feminine ones) which are particularly significant in the symbolic order of western patriarchal culture.

Adriana Cavarero points to some of these moments and figures in her book Nonostante Platone, and to their successive reinterpretations: the Greek gods and myths, then Homer's Odysseus, the Oedipus of Greek tragedy, Faust, Don Juan, and then the metamorphoses of these figures: the Oedipus of Freud, the Ulysses of Dante and Adorno, the Don Juan of Kierkegaard. Although the symbolic order can and does find other forms of expression, such as the philosophical treatise or law book, the power of a symbolic figure is incomparable for its communicative and evocative force. These mythic figures, argues Cavarero, have the power to concentrate within themselves, in a sort of paradigmatic incarnation, the symbolic order which informs them. Their metamorphoses, however, take place within the historical development of the same symbolic order, which from the beginning is under the sign of patriarchy. ${ }^{6}$ In it, a masculine subject, claiming to be neutral and universal, speaks its own centrality and locates around itself a world configured in its own image. Feminine figures have their place within this system as well, but always in reference to the masculine subject. For Zeus there will therefore be Hera, for Don Juan, Zerlina, and many others.

What happens, asks Cavarero, if one begins to reject the claim that this symbolic patriarchal order configures and gives meaning to the experiences of humanity as a whole? Once we question the centrality of male subjectivity, the entire symbolic structure of western culture with its male and especially female figures begins to fall apart. The need for symbolic and mythic figures, however, remains. Where should a feminine symbolic order find these figures? There are two possibilities, Cavarero suggests. One is to create them. The imagination of women poets is one of the places where this creation occurs. The other is to steal them. To steal them, that is, from their "original" contexts, and in so doing to transform them, to invest them with different functions and meanings; to invent different subtexts for them. This is indeed the prerogative of the feminine voice in Gargani's view. And this is exactly what Cavarero herself does, taking up a series of female figures who occupy a very minor place in Plato's texts: Penelope, Demeter, Diotima, a young Thracian servant girl. Cavarero's entire project, which includes the unraveling of some complicated philosophical questions, is under the sign of Penelope, of her work of weaving and unweaving, which comes to symbolize at the same time the undoing of western patriarchal thought and the construction of a feminine symbolic order. ${ }^{7}$ For in Cavarero's revisionist version of her story, Penelope works on two different looms. On the first one she weaves the figures of a feminine symbolic order, while on the second she undoes the worn-out tapestry of the fathers.

I would like to argue that there is a common project which several otherwise 
extremely different contemporary Italian women poets share. This project I call mythic revisionism, whereby these poets "steal" old stories and change them utterly, so that they can no longer stand as foundations of collective male fantasy, ${ }^{8}$ and become, rather, part of a feminine symbolic order. My first example is the myth of Orpheus and Eurydice. Orpheus is, from Ovid to Rilke and beyond, the quintessential figure of the male poet and his privileged object of desire and representation: woman. Why this myth should be particularly disturbing to women poets is made clear by an American poet, Alta. Of the passive Eurydice who exists only as the tragic object of Orpheus's love, she says: "All the male poets write of orpheus / as if they look back \& expect / to find me walking patiently / behind them. they claim i fell into hell. / damn them, i say. / i stand in my own pain / \& sing my own song."

Rossana Ombres's 1975 "Orfeo che amò Orfeo," a long poem which includes sections in both prose and verse, is an irreverent parody of both the classic myth of Orpheus and some stylistic features of canonical male poetry and poetic prose of the Twenties and Thirties. In Italian literary culture these two key decades of the seizure of power and the consolidation of the Fascist regime coincided with the era of ermetismo, a poetic tendency coupling rarefied, evocative but often impenetrable lyrical diction with an elegiac tone, and celebrating the "secrets" of self-made, small-scale and unassuming personal mythologies. Although politically and ideologically ambiguous, such mythologies (Montale's Occasioni, although not strictly a work of the hermeticist "school," would be the primary example) were interpreted retrospectively as poetic strategies of indirect "resistance" against the loud and violent mythologies of the regime, with its emphasis on the collective, the heroic, and the grandiloquent. Orpheus's journey into the underworld, his attempt - through poetry — to rescue the dead Eurydice and bring her back into the light became an allegory of ermetismo's mise en crypte of poetic discourse and its retrospective salvific claims vis-à-vis Italian literary culture in a season of obscurity and political oppression. ${ }^{10} \mathrm{~A}$ poem entitled "Dialogo" by Salvatore Quasimodo, published in the 1949 volume La vita non è sogno, gives a clear sense of the persistence of the myth of Orpheus and Eurydice in this salvific key and its political significance in the years immediately following the fall of the Fascist regime. The poem's speaker is a soldier coming home from the war, but he is also Orpheus mourning his Eurydice. Quasimodo skilfully superimposes the image of the loss of the lover on that of the loss and devastation brought by the war and the parallel loss of the Orphic poetic power to reclaim the dead. But this situation of loss is reversed by the end of the poem, when through the revivifying contact with the places of his youth and the recovery of his poetic voice, the poet envisions himself as capable of bringing Eurydice back to life and regaining his role as redeemer: "Euridice è viva ... E tu sporco ancora di guerra, Orfeo, / come il tuo cavallo, senza la sferza, / alza il capo, non trema più la terra: / urla d'amore, vinci, se vuoi, il mondo."

The symbolic function of the mythic material of Orpheus and Eurydice is not 
limited to the hermeticist "period," however. Dino Campana's Canti Orfici (1914) constitutes one of the most powerful and idiosyncratic occurrences of the myth in Italian twentieth-century poetry. The entire text is written in a visionary mode inspired by a Nietzschean version of orphism, and tells of the poet's journey of initiation and purification from earthly passions. While the repertory of female characters runs the gamut of misogynist turn-of-the-century stereotypes, the virulence of some of Campana's sadistic fantasies about women's bodies points in the direction of futurist and fascist misogynist violence: " $E$ allora figurazioni di un'antichissima vita libera, di enormi miti solari, di stragi di orge si crearono avanti al mio spirito. Rividi un'antica immagine, una forma scheletrica vivente per la forza misteriosa di un mito barbaro, gli occhi gorghi cangianti vividi di linfe oscure, nella tortura del sogno scoprire il corpo vulcanizzato, due chiazze due fori di palle di moschetto sulle sue mammelle estinte" (15). In the 1960 's, Campana was celebrated by the new (male) poetic avant-garde (especially Sanguineti) as its only authentic predecessor and a true innovator. The persistence of the myth of Orpheus in the Italian poetic tradition reveals an ideological continuity in the articulation of the male poet's (Orpheus) relation to his ambiguous female object of love, loss and representation (Eurydice), which transcends otherwise profound stylistic, thematic and political differences. ${ }^{11}$

In explicit opposition to hermeticist pretenses of timelessness, Ombres sets her poem in a contemporary, historically marked present: the era of the triumph of consumer capitalism and selfish self-interest after the loss of postwar illusions. In so doing, however, Ombres does not set narrow limits to her poem's critique. She roots her Orpheus in the present in order to reach all the more effectively into the past and question the presuppositions of the myth as well as its significance and uses within the patriarchal symbolic order. In Ombres's irreverent version, Orpheus is a narcissist in love only with the image of himself as a young man. Women are repugnant to him, and he looks at Eurydice in disgust: "La verità è che Orfeo aveva sempre pensato che le donne fossero insolenti, buie e miserabili." This fall of Orpheus from his exalted rank to a narcissist and misogynist is not just a sign of the times for Ombres. Rather, this latter-day Orpheus finally unmasks a syndrome that was always deeply embedded in patriarchy throughout the myth's metamorphoses from Ovid to Cocteau and after.

According to Cavarero the homosexual self-love advocated in Plato's Symposium reflects a fear of death and an obsession with the immortality of the soul whose corollary is a pervasive contempt for women as life-givers through the body, for bodies are destined to die. This contempt is coupled with a form of womb-envy (evident in the language of midwifery used by Plato's Socrates and echoed by poets from Dante to D'Annunzio), whereby the ability of women to give life is both both an object of jealousy and of scom because material rather than spiritual. The life-giving power of Orpheus in the classical myth, and especially his ability to give life back to a woman - Eurydice - through poetry, is on the one hand a symbolic usurpation of the life-giving role of women, and on 
the other hand a stigmatization of it as worthless because - unlike poetry - it is material rather than spiritual. Orpheus's ultimate loss of Eurydice is a punishment for his inability to transcend completely (the desire for) the material, for the body and its life. In Ombres's poem Orpheus refuses to take Eurydice back out of Hades because he finds her pregnancy revolting and threatening. She is, he feels (and actually imagines that he can see), about to give birth to a monster: "Il feto che porta nella pancia le traspare . . . La terra non deve avere più mostri!" (345).

In Ombres's poem there is no attempt to glorify Eurydice, however. Ombres's Eurydice - a fashion model who loved money and fast cars (she died in an automobile accident) and earned a living posing for ads for "Jesus" shorts - is a grotesque example of feminine alienation, of the debasement of woman when she becomes nothing but the prostituted embodiment of male desire. The loss of Orpheus's mythic identity in Ombres's poem and his dismemberment by the frenzied Maenads (a motley group of Roman whores from the "Raccordo anulare" taking their revenge because he does not want to have sex with them) corresponds to a loss of voice: "la sua voce chissà dov'è, forse è già sulla terra, finita nella gola di un uccello o, per estrema punizione, squittisce in un topo di chiavica." The voice of the poet here is not Orpheus's: rather it belongs to her, Rossana, who puts herself on stage with a flourish in signing her text: "Orfeo amò Orfeo / e la morte col suo infuriato esercito / offensiva e ributtante / abolì un amore così perfetto. / Con l'anima tutta rattristata / Rossana poetessa questa storia ha scritto."

Ombres's poem is shocking for at least two reasons. One is its grotesque debasement of a classical myth which concerns the very origins of poetry. The second is its low diction and obscene tone: both are as removed as possible from the kind of lyrical sensitivity associated with women poets. Indeed, the very writing of a long poem runs counter to the common expectations about women poets. Implicit in Ombres's revisionist retelling of the myth of Orpheus is a sweeping indictment of a kind of male-authored poetry that in twentieth-century Italy is associated particularly (but not exclusively) with the tradition of ermetismo and its aftermath. Implicit here is the notion that such poetry and much of the lyric belonging to the western patriarchal tradition is but a cover-up for selfindulgent narcissism and misogyny.

Ombres's critique extends to the language in which these contents are embedded, taking issue with its ambiguity as a coverup for the violence of representation: "Solo il vento ha la spavalderia / di dire Orfeo nei suoi ululati / ma così criptico è il suo linguaggio / una carezza può essere una feroce percossa" (353). Her own language has none of the ambiguity she chastises. Its violence is not the hidden violence of symbolic representation but the direct, explicit sarcasm of a latter-day Juvenal or Parini. Along with the mythology of Orpheus the male poet, Ombres rejects both the rarefied, cryptic diction of the hermeticist mode and the play with the polysemic potentials of language of neoavanguardia 
poets such as Sanguineti. This is in no way a "beautiful" poem; in many ways it is a very "ugly" poem, with a strong scatological undercurrent and an uncomfortable tendency to dwell on the most grotesque aspects of the body and its potential disfigurements, with none of Bosch's visionary appeal. But then, the kind of esthetic prejudice that makes me say this is precisely what Ombres's poem sets out to subvert. In all faimess to Ombres it must be said that I have chosen to focus on this poem ${ }^{12}$ because it is one of the clearest examples I know of a sharply critical mythic revisionism.

Ombres's version of mythic revisionism in "Orfeo amò Orfeo" is satiric and savagely critical but, for all its demystification of the myth and the language in which it is embedded, it does not provide either a countermyth or a counterlanguage capable of articulating a feminine symbolic order other than in negative, "destructive" terms. As in Montale's famous lines, what this poem tells us is only "ciò che non siamo, ciò che non vogliamo." There are, however, at least two other strategies of mythic revisionism in Italian poetry by twentieth-century women. One - which we might call the "constructive" approach (as opposed to the "destructive" one taken by Ombres) — subverts a powerful patriarchal myth by replacing it with a myth that "founds" (or restores) a feminine symbolic order. The poets who pursue this second strategy, while at odds with the dominant male tradition of poetic language, do not reject it completely. Rather, they take from it what they need to forge their own language and symbolic framework. The third strategy, which we might call "deconstructive," pursues the same kind of radical, demystifying critique as the first, but it neither believes that a radical break with the dominant male tradition and language is possible nor does it trust its own capacity for (re)creating alternative mythologies, even though it relentlessly pursues this possibility. Its language does not seek to expose or explode hermeticism and ambiguity, nor does it attempt to restore a fullness of signification capable of giving myth a firm grounding in truth or belief. Rather, it engages in strenuous, painful play with the resources of language and the poetic tradition to eviscerate them from within, to lay bare their ideological stratifications as well as their potential for difference. None of these strategies is necessarily superior to the others in my view, and while the third, typified by the work of Amelia Rosselli, holds the fascination of being the most complex and arduous, the second - for which I have chosen as paradigmatic examples the work of Maria Luisa Spaziani and Rosita Copioli - has the appeal of clarity, rhetorical efficacy, and a sharp political edge.

A short poem by Spaziani entitled "Mitologia" from the 1966 collection Utilità della memoria, may serve as an introduction to the second, "constructive" strategy of mythic revisionism. Spaziani takes mythic female figures associating woman with death (the Parcae or fates), destruction (Penelope unweaving at night what she wove during the day), and emasculation (the Danaids who killed their husbands with daggers and were punished by having forever to carry water in leaking jars), and turns these figures upside down. In her version, the Parcae's 
work of death turns out to be that of life itself. Unlike the thread-cutting Parcae, women, Spaziani claims, are rather thread-weavers, like Penelope. At night Penelope does not in fact unweave but rather re-weaves the threads which a "beloved hand" (presumably that of her husband, the warring Odysseus) has torn and cut during the day. And the Danaids' restless work, in another inversion, turns out to be not a futile act but one essential to life - the life that male violence constantly threatens. Spaziani rewrites these female figures not as destroyers but as saviors and life-givers. They are saviors, in particular, of other women, and of themselves. And it is male violence - sometimes the violence of the men closest to them - that has necessitated their taking on these roles. The truth, then, is the opposite of the "official" version. Spaziani's unassuming way of conveying her message (tentative at first but then - in stanzas two and three - unambiguously affirmative) is particularly effective: "Basta soltanto essere in vita, a volte: / e simili alle Parche / tagliamo i fili della vita altrui, / avveleniamo il sangue di chi amiamo. / Ma più sovente, forse, capovolte / Penelopi tra gli ospiti nemici, / ritessiamo di notte i cento fili / che va strappando la diletta mano; / come Danaidi senza mai riposo / ricolmiamo le vasche del respiro / che ci succhia (più stretto si fa il giro) / l'uomo lupo agli uomini."

Spaziani's language, here and elsewhere, has the virtue of clarity and concision. Even in such a short poem the classical elegance of her style is evident. "La diletta mano" is a phrase that echoes Leopardi and Carducci. Montale, Pascoli and the crepuscolari are other important influences in her work, as she charges autobiographical detail and confessional material with mythic resonance. ${ }^{13}$ Contrary to her male predecessors, ${ }^{14}$ however, Spaziani's central semantic axis - the mythic framework which persists throughout her poetry - opposes an economy of life and affirmation to one of death and negativity.

Spaziani's particular approach to re-vision consists of appropriating not only traditional mythic figures of the patriarchal tradition, but also the language of her male predecessors, while reversing their message. This is visible in another poem from Utilità della memoria entitled "L'antica pazienza," dedicated to the author's mother: "L'allegria rialza la sua cresta / di galletto sui borghi desolati, / come il lillà che ti cresce alle spalle / passo a passo, baluardo sul massacro. / Raccogli ancora e sempre il pigolante / nido abbattuto dal vento di marzo / e ripara le falle della chiglia. / Nessuno è senza casa se l'attende / a sera la tua voce di conchiglia." These lines (the last nine of the poem) interweave allusions to Pascoli ("il pigolante nido") and Leopardi ("galletto," "borghi desolati") and their respective semantic universes with, in the final five lines, an imperative and a closing sententia which are almost transparently molded from Montale, except that they carry a message of hope and being-at-home-in-the-world whose strength is alien to all three male poets. Although the centrality of maternal or life-giving figures in Spaziani's poems is hardly peculiar to women poets, male poets tend to celebrate maternal figures from the point of view of death rather than life. ${ }^{15}$ 
Whether the concern with death and negativity may be extended beyond Spaziani's three male predecessors to the entire corpus of western poetry written by men is a question whose implications are beyond my scope here, but I will nevertheless pursue it briefly in light of my discussion of mythic revisionism. In his poetically and philosophically-charged essay "Il remo di Ulisse," the contemporary poet and critic Luigi Ballerini concludes his reading of Odysseus's second journey by stating that "La poesia si costituisce come esercizio di fronte alla morte" (138). For Ballerini, all of Odysseus's skill and resourcefulness never represent an epistemic breakthrough for him. His coming home is merely a restoration to his wife and land, the stuff of which narrative prose, not poetry, is made. He will be restored, that is, to a world of (implicitly inauthentic) limits and institutional meanings and feelings. Only with his second voyage, where, according to Ballerini, Homer intimates he will encounter death, will he also acquire a different form of cognition, coinciding with poetry:

Di questo secondo viaggio Omero non dà che gli accenni menzionati [ . . .] Essi sono tuttavia sufficienti a suscitare (al di là della 'cerimonia narrativa,' che, come si è detto, costituisce la 'materia,' la 'prosa,' del primo ritorno), la 'ritualità necessaria,' la 'poesia' del secondo, intesa, quest'ultima, come attività il cui senso gravita intorno a, e trae vita da un conoscere distinto dal riconoscere con cui è, anzi, in antitesi. (136)

In Nonostante Platone, Adriana Cavarero expresses a similar view of the meaning of Odysseus' last journey as centering on the experience of the limit and of death, but she opposes to this an anthitetical reading of Penelope and the symbolic significance of her experience after Odysseus' last departure. Her reading is based on an interpretation of the crucial image of the sea as "il limite," which forms the core of a poem about Penelope by Bianca Tarozzi: "Ora discesa / sulla riva, dal mare risuonante / sente voci lontane, antichi naufraghi, / fantasmi che la vogliono afferrare: / tutte le guerre che non ha perduto / né vinto, / tutti gli amori che non ha vissuto / il dolore e il furore degli eroi, / che non le spetta: / scempio, / dolce urlare del vento / dentro l'anima. / Ritorna sui suoi passi. / L'esperienza / del limite per lei / è l'acqua incollerita della riva — / per Ulisse lo schianto / e la fine tremenda / contro gli scogli, verso la leggenda."16

While the sea grants to Odysseus an ending adequate to the meaning of his existence (he cannot die at home, because he is, Cavarero says, the "elsewhere of eventful action"), for Penelope the sea-shore marks the experience of the limit. Penelope's and Odysseus's experiences of the limit are conceptually "asymmetrical," argues Cavarero. For Odysseus it is death which measures the limit. The sea is the place of that limit because the threat of death is always present in it, not only because the sea is dangerous but because it leads to occasions for death: Polyphemus, Circe, the Mermaids. Shipwrecks, transits and arrivals turn, every time, into another potential death. Odysseus experiences the limit almost as the goal of his wanderings, before yielding to it once and for all. Each 
of his adventures is but one trial in a series which leads to the definitive one. Death constitutes the border, the limit of his realm. Yet death is also always present because it is always challenged, and is the measure of the challenger's strength. Indeed in Homer's world of "i mortali" - Cavarero concludes - only legend defeats the limit and gives eternal life, and only the human challenge to the limit can become legend.

For Penelope the sea represents the limit in an altogether different way. The realm of death borders on her house — her island — but only as a foreign region of "wars that she has neither won nor lost," events that do not concern her and that she does not know. For her, the place of the experience of the limit is not the whole sea, with its irresistible ambush of death, but only the circumscribed shore. Although this limit may be seen as a confinement imposed by the patriarchal order, this is so only if we adopt that order's critical perspective, Cavarero claims. If we look at it with Penelope's eyes instead, we see the shore not as a prison, but as that which excludes, holds at a distance, an alien world inhabited by men. Penelope knows that the sea is Odysseus's, and lets him go and stake the meaning of his being on his confrontation with death. She, for her part, does not resign herself to the confined role Odysseus has imposed on her. Penelope turns her room into her own legend:

La vedo ridere con le ancelle mentre insieme tessono vesti ad esse confacenti, narrando di come tennero in scacco i Proci insieme scoprendo la letizia di quello stare fra di loro lavorando e pensando. La vedo, le vedo, in quell'isola, che ora straordinariamente separa con mitica chiarezza due mondi estranei, parlare di nascita e di radicamento piuttosto che di morte e di avventura, guardando dalle finestre quel limite di acqua incollerita che le separa dalle gesta degli eroi e consente loro di stare su una terra ben ferma dove il gesto tesse un primo luogo non più minacciato di libertà femminile. Un primo orizzonte di appartenenza il quale lascia altrove il maschile affaccendarsi in quel regno della morte che esso ha scelto a sua misura e a limite estremo dei suoi sanguinosi orizzonti. (23)

Cavarero's text on Penelope is indeed, as is apparent from this passage, a prose poem, and as such it intends to mark a different way of "thinking," of doing philosophy, outside or on the margins of the patriarchal tradition. The image of Penelope with her maidens in the house, laughing and thinking ("laughing" as a form of demystification of the "foundational lie" of western philosophy forms the subject of the second chapter of Cavarero's book), may be read as an allusion to the Diotima group (or rather, as they call themselves, "philosophical community") of women philosophers, which includes Cavarero and Luisa Muraro. Cavarero's and Muraro's philosophical works are attempts to delineate that "other" mode of thinking and that "first horizon of belonging" that Cavarero attributes symbolically to Penelope and her women.

Central to such a new mode of thinking is Hannah Arendt's notion that throughout the history of western philosophy we find the persistent, singular idea of an affinity between philosophy and death (to which Arendt wishes to oppose a 
form of thought rooted in the life-giving). The first philosopher to express such an idea is Plato in the Phaedo, when he says that the philosopher appears to those who do not do philosophy as someone pursuing death. Although Orphism is the direct predecessor of the Platonic theory of "living for death," it is Plato's thought that comes to have a determining influence on the entire course of western philosophy, argues Cavarero. And it is to the Phaedo that Cavarero turns to show that death is as central to the project of western metaphysics as it is to the wanderings of Odysseus. The (male) poet (Ballerini's Odysseus, but also the poet as Orpheus of the hermeticist tradition) and the (male) philosopher yearn for a form of cognition only death can yield. ${ }^{17}$

Plato argues that philosophy, by taking thought towards the eternal objects (ideas) suitable to it, unbinds the soul from the mortal body. Those who lament death (Socrates' death is imminent) are bad philosophers, because death is but the definitive unbinding of soul from body. Plato compares these bad philosophers to Penelope, because they want to bind again that which they have unbound with philosophy, in an endless work that renders vain what has been achieved. Cavarero notes that the metaphor is strange, because it uses an inversion: the absurd act for the philosophers is to re-weave what they have undone, while for Penelope it is absurd to un-weave that which she has already woven. But Plato's strange or inverted use of the metaphor allows Cavarero to make Penelope the symbolic figure of a philosophical mode antithetical to Plato's. Plato's metaphoric play allows us to see Penelope's weaving as a reuniting of the soul with the body. As with Penelope and her women, there is in Plato a notion of dwelling or home, but it is not, like the weaving room at Ithaca, on this earth; it is not a being-at-home-in-the-world. On the contrary, for Plato this world and the life to which one is born represent a form of estrangement. Birth itself is seen as negative, the fall of the soul into the body, matter, passions, desire. For the soul this sojourn in the body represents an imprisonment from which the exercise of philosophy can begin to free it in expectation of that definitive liberation which death will bring by lifting up the soul once again to the realm of ideas.

Plato's philosophy, Cavarero points out, is based on a semantic estrangement separating the concept of life from those of birth and death, although the latter belong to every living being's experience of life. It is the life of the soul, an eternal life without birth or change or death, that becomes the paradigm, so that life loses its connotations of birth and death, leaving these to the body, which is correspondingly devalued. This complex operation of semantic estrangement and devaluing of the body marks the crucial beginning of a process of "de-signification of the necessarily corporeal dimension of living, which in turn inhibits the symbolic translation of sexual difference" (27). "In other terms," she continues, "a corporeality that is separated and de-realized lends itself more easily to not being seen in its sexual connotation, always marked by difference, so that the male sex can more easily pretend its neutrality and universality." The work of Cavarero and the other women of the Diotima group seeks to restore to thought a 
series of dimensions (first and foremost that of sexual difference) which the "foundational lie" of western metaphysics has systematically excluded since Plato. Opposing the devaluing of the real and of material experience inherent in Platonic thought, Cavarero and the Diotima group seek to elaborate a form of thought in which the fundamental categories are, along with sexual difference, the experiences of birth, receiving and giving life, the link with the mother, the body, and the notions of dwelling, at-homeness and rootedness. Penelope the weaver, after Odysseus's last departure, becomes the symbolic figure for such thought:

Penelope è appunto tessitrice, e ora forse, per merito di Platone, sappiamo cosa continuò a tessere, con le ancelle, quando l'evento ultimo si compí per mare lasciandola quieta nell'esperienza del limite che tracciava la sua appartenenza. Continuò a tessere quell'interezza singolare di corpo e pensiero che già nella sua metis si era manifestata, quella realtà dove vivere è soprattutto nascere e poi, solo alla fine, anche morire. Quell'intreccio di intelligenza e sensibilità dove ogni umano vivente - non anima eterna caduta in un corpo qualsiasi, di qualsivoglia specie o sesso esiste nella sua specie e nel suo genere: lei, come le ancelle, donna, a tenere insieme intessuti $\mathrm{i}$ pensieri e i corpi loro in una propria casa che lascia altrove la palestra maschile della morte. (31)

In Cavarero's outline of a feminist mode of philosophical thought, the categories of birth — being born, and giving birth — and the figure of the mother are paramount. Cavarero proposes a new reading of the myth of Demeter. The myth tells that when Demeter's only daughter, Persephone, is taken away from her to marry Hades and live in the underworld, Demeter witholds her gifts from the earth, which becomes sterile. The threat of sterility and death convinces Hades to send Persephone back to her mother for a brief period each year, in the Spring when fecundity returns to the earth. The central theme of the myth, according to Cavarero, is maternal power, inscribed in the whole of nature - the power, that is, not only to generate, but not to generate, to give and to withold life. The devastation and silence Demeter's grief brings to the earth, are to be read as figures of a traumatic response to the violation of an original maternal order. Hades, with the complicity of other male divinities, raped Persephone and deported her to the kingdom of death. The symbology could not be clearer: to the feminine order of birth and life-giving is opposed a masculine order of death. Towards the end of her book, Cavarero cites The Passion According to G.H., a work of poetic prose by the experimental Brazilian woman writer Clarice Lispector. Cavarero takes Lispector's itinerary of self-discovery as an emblem of a philosophical itinerary radically different from that of patriarchal thought. Taking the form of a daughter's address to her mother, Lispector's reflection on life and death succeeds in "destructuring the centrality of the omnipotent and bodiless self which had grown up feeding on the metaphysics of nothingness. Lispector does descend into the neutrality of impersonal life, but not in order to find simply the annihilation of the self there. On the contrary, she finds once 
again that maternal and sexed root that binds each self to impersonal life itself, and every living being to its beginning" (117). The fundamental coordinates for retracing a feminine symbolic order, Cavarero concludes, consist in taking the here and now of the living singular human being and looking backwards, to the past: "towards a rootedness that preserves the meaning of origin, rather than forward, foreseeing and projecting limits and obsessive ways of defeating individual mortality" (119). The backwards glance of the singular human being encounters first of all the figure of a mother who has given birth to him or her. And the mother - Cavarero says, paraphrasing Lispector - is in many ways the threshold "between the irreducible and full given of each singular living individual and the world from which this singularity comes and against which it takes relief: a world that already is, that exists before (and also without) this singularity" (120).

With its rejection of Cartesian scepticism as well as of Platonic idealism, and its richly suggestive notions of the need to look back to an origin, of the mother as threshold, and of a feminine economy of gazes that alone can mediate the recovery of a feminine symbolic order, Cavarero's text lays the foundations for a feminine / feminist metaphysics. For indeed, despite its emphasis on the body, experience, and the incontrovertible reality of sexual difference, hers is not a traditionally secular and materialist mode of thinking. Although Marx, Gramsci, Freud, and Nietzsche have all visibly influenced her thought, the crucial step of positing sexual difference as a fundamental category of thought is not the only discriminant between her way of thinking and theirs. Unlike them, she is essentially not so much a secular thinker as a "religious" thinker. I do not mean that she posits the existence of a God or that she falls into any recognizable theological "school." Yet it is from Irigaray's work that Cavarero and other women philosophers of the Diotima group develop a sense that feminist thought needs to believe in belief, and particularly in the belief in an origin - hidden and sacrificed - from which alone the meaning of a (repressed, displaced) feminine symbolic order can issue. In Cavarero's reading of the myth of Demeter, for example, the possibility of a feminine economy of gazes and a mother-daughter bond is predicated on that bond having been there originally, and on its having been hidden and sacrificed by patriarchal violence. This is precisely Irigaray's version of the "myth of origins." The hidden act of violence that stains (and founds) western civilation is not - as Freud thought - a patricide, but rather (as Euripides suggests in the Oresteia) a matricide. Reinterpreting Heidegger's diagnosis of the destiny of western metaphysics and its fulfillment in a modern world plagued by the triumph of technology, Irigaray points to the sacrifice of the mother and the rejection of living nature as the beginning of that collective forgetting of being which has led the world to its self-destruction, because it has forgotten its vital origin. The sense of this vital origin can be recuperated only through the restoration of a female genealogy, that mother-daughter bond for which - to Irigaray as well as Cavarero - the myth of Demeter and Persephone 
is the most pertinent figure. ${ }^{18}$

While Cavarero maintains a degree of reticence vis-à-vis the restoration of a metaphysical dimension to philosophical thought, and the need for a grasp of the "sacred," and prefers elegant literary allusiveness to direct statement, Luisa Muraro is an unabashed advocate of metaphysics, and openly discusses mysticism in her short book, L'ordine simbolico della madre. This strange, partly autobiographical book is written in a straight-forward, colloquial and at times almost pedestrian style that intentionally breaks with the traditional difficulty of philosophical jargon. The book includes its own commentary and self-critique, in the form of endnotes, and thus rejects the traditional format of the finalized, polished philosophical tract, taking on an appearance which, following Bakhtin, we might call "dialogical" in that it is constantly open to (self-)questioning and seeks to incorporate the perspectives of other women. "The unruly appearance of my writing," Muraro explains, "is due to the fact that my writing obeys rules that are still little known or not yet established" (64). The language Muraro seeks to adopt evolves in part from the author's experience of dialogues with other women and the so-called "pratica dell'autocoscienza" of the Italian feminist movement: "The practice of consciousness raising [presa di coscienza] leads one to discover that the real world is that which is given in our experience through the word and in the word through experience. This discovery is equivalent, in my view, to the rediscovery of the point of view of the origin, when the world was born along with us and our learning how to speak" (80). Muraro's book is based on a basic, fundamental "intuition" (as she calls it), which represents a turning point in her thinking and writing. For Muraro the entire history of western philosophy is the story of the alteration and therefore the oblivion of the meaning of being initially glanced at in the Greeks' most ancient thought (Parmenides's fragments in particular). This oblivion, Muraro claims, is due to one cause: the cultural repression ("rimozione") of our relationship with the mother, by which she means literally the woman who gave us birth as well as, symbolically, the matrix of life itself.

The loss of the mother and the loss of the truth of being are one and the same for Muraro. Hers is an unabashedly metaphysical statement, and she acknowledges metaphysics as the proper sphere and tradition from which her discourse stems: "Metaphysics is where truth rules as the meaning of being" (25). Muraro defines being for metaphysics as "the energy capable of driving back [respingere] nothingness [il nulla] away from itself" (26). "I accept metaphysics," Muraro states at one point, "but I reject that which in metaphysics tends to render superfluous the work of the mother and to invalidate its authority"(73). Muraro rejects, that is, all forms of nihilism, which she perceives to be the tragic consequence of the repression and loss of the mother.

Nihilism takes three major forms, in her view. One conceives of being as originally limited by nothingness and destined to end in nothingness - a being that is absurdly indifferent to being or not being. The second form separates be- 
ing from thinking and conceives of them as mutually independent. Finally, the third conceives of being as indifferently true or false. It is a nihilism of being as fiction, of being as simulacrum, whose principal resource is that of being believed to be true (29). ${ }^{19}$ The authentic sense of being must be rescued from these three forms of nihilism. Muraro, like Cavarero, cites The Passion According to G.H. as a crucial feminist text. For Muraro, it is an example of a mystical-poetic discourse which succeeds in recovering the pure presence of being (the unsayable) through an experience of the failure of language. Mysticism, Muraro asserts, is a "shortcut" to the recovery of being to which women often resort (she points out that the mystical tradition is mostly a women's tradition).

Muraro is careful to distinguish between her notion of "the mother" and her symbolic authority and a theological notion of God: "The maternal greatness of which I speak is of a symbolic, not of an ontological order [. . .] I do not see greatness in the fact of putting children into the world [. . . The woman who has put me into the world is great because of her precedence, for her being upstream of every one of my choices and my greatness, which gives her a unique and unmatchable greatness, not substantial in itself but for the position she definitively occupies" (129). Muraro's is a metaphysics of the origin, fully inscribed within the tradition that post-structuralist philosophers such as Derrida and Vattimo have sought to deconstruct or "weaken." Paradoxically, metaphysics, which has come to be viewed in the postmodern era as fundamentally mystifying and oppressive, acquires, from the point of view of Muraro's feminism, an unexpectedly radical and liberatory potential for women.

What leads women mystics - asks Muraro - to skip altogether the "step of beginning to tell the truth, and to aim instead directly at the unsayable in order to leave fiction [the fiction of nihilism] behind?" (33). And, she asks, "what leads those who do instead commit themselves to the regime of mediation [language], much too often, to failure?" One answer is the inadequacy of patriarchal language to serve as a tool for women's self-signification. But the inadequacy of language as mediation is due first and foremost to a lack of an authentic symbolic authority for women, the authority to affirm "what is" which language does possess and which we acquire when we learn how to speak. While it is true that language, as a social product, reproduces the historical condition of the female subject in the system of social relations, "language is not reducible to a product, being in turn a producer of the social, and this from the time of the exchange of life and the word with the mother. As such, it is capable of assisting effectively women's coming to consciousness [presa di coscienza] and to the word" (130). The apparent inadequacy of language, Muraro affirms, thus arriving at the core of her theory, can be overcome only by recovering in our adult lives the original relation with the mother and adopting it as a principle of symbolic authority. It is the original relation with the mother which "gives us a lasting anc' true point of view on the real [...], true in accordance with the metaphysical truth that does not separate being from thought and nourishes itself with the 
reciprocal interest of being and language" (46).

One of the fundamental myths of patriarchal culture (a kind of original "theft of language") is, according to Muraro, the notion that "as culture separates itself and us from nature, so it is necessary that we separate ourselves from our mother and turn our back on the experience of our relation with her, in order to enter the social and symbolic order, the principal agent of this separation being the father" (42) ${ }^{20}$ On this myth is predicated the notion that "it is a structural characteristic of the symbolic order that our experience of our relation with the matrix of life cannot be expressed and does not therefore constitute a point of view. This perspective - the cornerstone of the Lacanian concept of language and the symbolic order - is in Muraro's view false, because "we learn to speak from our mother or someone who functions as mother [. . . and we learn to speak as part of our vital relationship with her" (42). Contrary to Julia Kristeva, who in Revolution in Poetic Language posits the loss of the original relationship with the mother and the separation from her (the "thetic cut" or "break") as necessary for the child's entry into the symbolic, Muraro argues that the symbolic order necessarily begins to establish itself in the relationship with the mother, and that the "break" which separates us from her is not an inherent structural necessity of the symbolic. Rather, the "thetic break" describes a historically determined, contingent symbolic order, the symbolic order of patriarchy where, as stated by Luce Irigaray, men have usurped the power of the mother, destroyed her genealogy, and inserted women, one by one, into male genealogies instead. ${ }^{21}$

Can the symbolic order be changed, asks Muraro? Yes: a change can occur in the symbolic through the practice of autocoscienza, which amounts to a revolution: "In order to understand what this revolution is, we need to reconsider the symbolic order by not limiting it to reconstructible codes (such as the economic system and the political one, the law, etc.). [. . .] We need to reconsider it in terms of its actuality, as a system of mediations on which I depend in order to say what I am saying and what I am unable to say and in general all that it is sayable and desirable for me, etc. It is at this level of mediation [. . .] that the symbolic order reproduces itself and can be changed. [. . . But can we plan to change the symbolic order? That it can change is shown by history. But does it make sense to conceive of a politics for its modification, as I suggest on the basis of the women's political movement? I think yes. The symbolic order belongs, without doubt, to the deep structure of human reality, which makes us be this way or that way unbeknownst to us. This, however, does not exclude, I believe, the possibility that it can become the object of a modifying intention" (93-94).

As Muraro acknowledges, her idea of an "accordo" between being, the real, and language - mediated by the mother - echoes the notion of an original concord between subject and world formulated by the German philosopher of language von Humboldt. Paul de Man identified the symbol-allegory dichotomy in pre-romantic and romantic literature as the difference between, on the one hand, a world — the world of the symbol — in which it would be possible for 
language and image to coincide with being, and for the self to identify with the world (or non-self) from which it springs, and, on the other hand, the world of allegory, where no such identification is possible - for allegory "designates primarily a distance in relation to its own origin, and, renouncing the nostalgia and the desire to coincide, it establishes its language in the void of this temporal difference" (207). Unlike Muraro, whose entire project is precisely under the aegis of the symbol, de Man himself denounces the symbol as a mystification and attributes to allegory authenticity and truth: "[Allegory] prevents the self from an illusory identification with the non-self, which is now fully, though painfully, recognized as non-self. It is this painful knowledge that we perceive at the moments when early romantic literature finds its true voice" (207). Muraro's perspective - which would inscribe de Man's stand within the forms of nihilism she denounces - allows us to rethink the ideological (patriarchal) bias of de Man's preference for allegory as a rhetorical strategy. Allegory is the dominant figure of the historical avant-gardes first, and of modernism and the post-modern. $^{22}$ But allegory is also, in Benjamin's influential definition, the figure of death and mourning, which seeks to destroy all "illusion" of organicity and totality of being. In this light, the apparently retrograde return to the symbol as a rhetorical strategy, and the anti-modernist, anti-avant-garde stand of a poet like Rosita Copioli, assume a particular interest, especially since she seems to have taken Muraro's impassioned philosophical manifesto to heart, and to have placed her entire poetic endeavor under the sign of the mother.

"My youth having been afflicted by the avant-gardes of the 1960s," writes Rosita Copioli in a recent autobiographical statement, "I remained faithful to myself with my work on myth, nature, and the imagination" ("Per l'anniversario," 100). Copioli's second volume of poetry, Furore delle rose, starts with a section significantly entitled "Origini" which in turn begins with a long poem devoted to a mythic mother, "Mater Matuta." Impressive for its formal elegance, elevated style and diction, and complex rhetorical figurations, this poem takes the form of an address and prayer to the mother comparable for intensity and sustained breadth of vision to the highest compositions of two of Copioli's male predecessors: D'Annunzio and W. B. Yeats.

Copioli's admiration for Yeats is documented by her excellent critical work on him. ${ }^{23}$ The strength of D'Annunzio's influence is less obvious, due in part to D'Annunzio's peculiar history of reception in modern Italian literary culture, where, for reasons that have little to do with the intrinsic value of his texts, he became associated with "decadent" fin-de-siècle excess and shallow formal versatility on the one hand, and with reactionary politics on the other. No Italian poet as a consequence openly admits D'Annunzio's influence, although no one writing poetry in Italy in this century is unmarked by his poetic presence. It is curious indeed that Copioli should find in D'Annunzio and Yeats - whose exploitation of a repertoire of degrading images of women is well known - a source of inspiration. I do not mean that Copioli is in any way a "Dannunzian" 
poet. What she does take from D'Annunzio (I am thinking of the epic D'Annunzio of Maia and the "Laus Vitae"), and, to a lesser extent, from Yeats, is a propensity to speak poetically in an elevated, visionary style, of matters pertaining to the sacred, the origin, and myth, and at the same time of the lyrical self.

Copioli avoids the fragmentation and syncopation of neo-avant-garde poets such as Sanguineti, opting rather for a full syntax, distended rhythms and a sumptuous imagery. Like D'Annunzio, Copioli makes abundant use of complex figures such as paronomasia, oxymora and chiasmus, in ways which are creative (in the sense that these figures help to generate new, surprising consonances of meaning) rather than simply decorative. She also avoids the rhetoric of the unpoetic that marks many exponents of the neo-avant-garde. Unlike Giulia Niccolai, for example, she avoids the post-modern tic of shunning traditional poetic diction and imagery by resorting to the visual impact of advertising and the mass media, or alienation devices such as multi-lingual diction and extreme forms of colloquialism. ${ }^{24}$ Like D'Annunzio, Copioli fuses personal mythology with universal cosmology, and her work is studded (again like D'Annunzio's) with allusions and references to classical literary texts, myths, and narratives. Hers is not just a commentary on myth, but an attempt to create myth. In "Mater Matuta" in particular, a threshold poem to the book, Copioli seeks to create the myth of an empowering female figure - a mother and muse - who will give her the strength to speak and to be at one with being and the world.

While this is a common enough move in romantic and late-romantic poetry by male authors (D'Annunzio inserts his own "Inno alla madre immortale" in the Laus Vitae), it is uncommon among women poets. There is something perhaps uncanny (in that it might disclose the return of the repressed) in a woman poet addressing a woman mother-muse. This is indeed one occasion when the gender of the poet and of the subject of enunciation (in Benveniste's terms: the one who says "I"), does make a glaring difference. For the apparition of this mother-muse in a poem by a woman dispels the patriarchal myth that all women are destined to inscribe themselves in an Electra-like scenario. Copioli, instead, envisions a scenario in which the very origin of poetic language, the ability to speak poetically, is predicated upon restoring the lost link with the mother which patriarchy has repressed. (It is due to the difficulty of restoring such a link for women that Kristeva has stressed what she supposes to be their inability to tap the resources of the imaginary [the "semiotic" in her terms] and to produce writing comparable to that of such male avant-garde authors as Joyce and Mallarmé).

The Mater Matuta is the Greek goddess of the dawn, and Copioli's poem is about the dawn in more ways than one. The occasion, the epiphany or "intermittance du coeur" which coincides with the fictional moment of enunciation is in fact the moment immediately before dawn during a journey by train along the seashore somewhere in Southern Italy, when the eyes of the poet are 
struck by the first presages of sunlight on the water. She remembers a similar moment when, as a child, she used to see a glimmer of light reflected in the bedroom mirror from the barely open door and feel the gaze of her mother coming in to watch over her sleep. The traditional, but here creatively reinterpreted, paronomasia - "madre-mare" - plays an important role in the poem and may be said to be the implicit subtext of the epiphany that triggers the enunciation: "Madre mattutina, dalle porte / dei tamerici, nata dal tessuto / della pietra serena, / madre antica, ora remota, che mi appari / dalla finestra d'alba d'un treno / precoce / che corre sul mare, prima del risveglio / del sole, si alza appena il primo / taglio grigio dell'acqua, e non è ancora / luce, e come allora, ricordo, / mi custodivi il sonno, entravi / a guardarmi, sentivo dallo specchio / una luce, avevi dita di mandorle / e carminio, e ora, nel buio più alto / in cui sei, forse dischiudi altre porte, / sei custode di porti, mutata d'egida / come la vedetta prima, con gli occhi / di rapace; i piedi ti fremono / sul mare stellato. / Madre mattutina, da queste pozze / algide che fuggono, dove la terra / perduta pare donarci le stelle, / ricordi, sussurri ancora: / 'inizia,' / e mi prendi sul fianco, / e spingi il mio piede: / "va'?" (7).

The theme of the mother's gaze - as in Cavarero's notion of a feminine economy of gazes - coupled with the image of the mirror where mother and daughter recognize each other, recurs throughout the poem and becomes the symbol of the empowering poetic identity which the mother alone can confer on the daughter, and vice-versa: "Madre mattutina," the poem concludes in a final imploration to her for poetic power, "madre della polvere / del latte e dell' argento, / che fai nascere il sole dal cavo / della notte delle onde / infinita, / guardami, con te sulle sponde / di questo vetro / dove seguo un nastro di luce, / luce, / ti inseguo." The vision of the cosmic body of the mother culminates in the spectacle of the universe encircled by "un ovario immenso"(12).

In explicit and polemical opposition to the Lacanian theory of the mirror phase, according to which the formation of the subject (and its gaining access to language) is a process of estrangement from the (m)other, Copioli sets up an alternative identity, which binds once again the daughter not only to the mother but also, through her, to the entire universe, altogether undoing the Lacanian paradigm. Through a complex process that Gayatri Spivak has called "rememoration," the symbolic reworking of the meaning of one's being a daughter or son (195), Copioli projects the possibility that her mother is a link between her and the great body of Indoeuropean myth. "Madre Matuta," Copioli tells us in a note explaining the poem's more arcane allusions, is a conflation of a complex genealogy of feminine figures and goddesses, including Carna, the Roman goddess of food (but also of entrails and the most "secret" parts of the human body); Tacita, the goddess of silence; the Egyptian goddess Thueris, giver of milk; Nemesis, who, raped by Zeus, generates Helen in vengeance; Helen herself, "torch of tragic beauty"; Minerva-Athena, the goddess of wisdom, war, and all the liberal arts; the Mediterranean Maya, originally an androgynous 
Libyan goddess of the sea and the source of all creative impulses in nature; and finally Aphrodite-Venus, her game of love and death understood not only in the terms of Lucretius and Homer, but of the Upanishads, in which the universe is born from death and hunger.

This intricate network of mythic figures, while covering with a characteristically Dannunzian sweep the entire structure of the human experience of nature and culture, the body, time, desire, and the mind, is also beautifully simple in leading everything back to a feminine and maternal principle. Copioli's metaphysics of the mother, however, is more subtle and less simplistic than Muraro's admittedly tentative statement about the need to return to the mother as a fundamental principle of being. Copioli, for one thing, although confident of the power of the symbol (and of a "maternal" language) to signify fully the presence of being, expresses some doubt in her poems about her own ability to extricate herself from the realm of patriarchy. In effect, all the mythic feminine figures she refers to, while symbols of a maternal and feminine realm, are also known almost exclusively through their problematic representations in patriarchal culture, and are therefore essentially ambivalent.

None is more so than Nemesis, whose very name defines her in terms of mimetic revenge against the violence of patriarchy. Nemesis is that revenge and nothing else. Copioli feels that she herself is - at least in part - a daughter to Nemesis, that her bond with the mother does not exonerate her from the destructive compulsion of male-generated violence, which for a woman becomes, in the end, self-destruction: "Anch'io nell'illusione del mondo, / violenta, raddoppio le vendette / contro di me ... Nemesi, / slitto dal litorale lastricato / senza che l'alba fasci una speranza" (11). Violence and death are important themes in Copioli's poetry, and the face of the mother is, like that of Janus (the other presiding deity of Furore delle rose), always double, doubly posed to look towards life on one side, and death on the other. Yet life and life-giving remain as in Spaziani, Cavarero, and Muraro - dominant principles in Copioli, and death enters into it not as the most authentic moment, from the anticipation of which all thinking and poetry springs but, on the contrary, only a part, a natural part, of life. The overall sense of this visionary poem is of an extraordinary life which emanates, through the poetic work of rememoration, from the word of the "madre-mare."

While Copioli shares with Spaziani and - in different ways - also with Cavarero and Muraro, the notion that a feminine symbolic order can be constructed or restored through the appropriation and alteration of existing mythologies or the creation of alternative ones, Amelia Rosselli takes a more sceptical, disenchanted approach to the question of mythic revisionism. Her approach may be called "deconstructionist" in that while it works to dismantle the assumptions of patriarchal discourse on women, it does not share the metaphysical beliefs of the Diotima philosophic community and of poets such as Spaziani and Copioli, although it gestures towards the possibility of a different language that might not 
be entrapped in the logic of the patriarchal symbolic.

At least three poems in Rosselli's work deal explicitly with mythic feminine figures: "Perché il cielo divinasse la tua ansia di morire," "Nel letargo che seguiva l'ingranaggio dei," and "Mare del bisogno, Cassandra." All three poems are from Variazioni Belliche, and involve three mythic Greek heroines: Electra, Antigone, and Cassandra. I will focus my analysis on the Antigone poem, because it is there that the philosophical and political implications of Rosselli's approach appear most clearly. Since the poem is short, I will cite it in its entirety: "Nel letargo che seguiva l'ingranaggio dei / pochi, io giacevo, felice e disonorata, disordinata / all'estremo; e le lingue dei serpi s'avventavano / come fuoco vicino al capezzale. Vicino al capezzale / moriva un drago, salumiere con i suoi salumi, le / sue code che pendevano molto puzzolenti, ma delicate / nel loro odorare insieme. // E se l'antigone che vegliava silenziosa, molto silenziosa / ai miei poderi i miei prodotti disordinati, disadorni / di gloria, se essa fosse venuta col suo gradito grido / d'allarme, io morivo, molto silenziosa allarme" (88).

As usual with Rosselli's poems, a first reading is rather forbidding, and the text presents an opaque, almost impenetrable surface until we perceive the "formal messages" which sound patterns and other repetitions and correspondences generate at the level of the signifier. The key organizing principle of the text appears indeed to be phonetic, a kind of "grid" centered on the repetition of a hard "g" sound: "Letargo," "seguiva," "l'ingranaggio," "drago," "gloria," "gradito," "grido." This is, however, also the central sound of the word "antigone," which at the beginning of the second stanza after the central caesura of the poem, so that the poem's phonetic rotation around this sound implies its being centered semantically on the figure of Antigone and what the poet sees as central and essential to this figure. The other dominant pattern at the level of the signifier is an emphasis on the privative prefix "dis-" which occurs four times: "disonorata," "disordinata," "disordinati," "disadorni." The repetition of this prefix, with its negative force, suggests that the theme of being dispossessed is also crucial.

Unlike Copioli's text, where the integrating, organic symbol is the dominant rhetorical figure, Rosselli's poem is essentially allegorical in the fragmented, montage-like and non-organic manner characteristc of the avant-gardist work of art. ${ }^{25}$ Death and mourning - elements inherent in the allegorical by definition, according to Walter Benjamin - are the key concerns of this poem's revision of the Antigone story. The one who says "I," whom I will call, in light of her reference to her poetic work later in this highly self-reflexive text, "the poet," describes her state as one of "letargo" - a condition of unconsciousness or semiconsciousness, like sleep, and like, or even near, death. The poem that follows in the collection (which, as throughout Variazioni belliche, is linked to the preceding poem thematically and phonetically), opens with the line, "Se dalle tue lun. ghe agonie e dai miei brevi respiri," where the word "agonie" not only echoes "antigone," but also spells out the theme of agony which in the previous poem is 
only alluded to. The second half of the long opening sentence, "e le lingue dei serpi s'avventavano come fuoco vicino al capezzale," reinforces the sense of lying near death while it evokes an odd scene of martyrdom seemingly taken from early Christian iconography. This would explain to some extent the series of seemingly contradictory adjectives: "felice e disonorata, disordinata / all'estremo." The "extreme" dis-order and dis-honor of the martyr's tortured, scattered body in this moment of agony ("all'estremo" both qualifies the the adjectives that precede it and also means "at the end, near death") produces a sort of ecstasy, a happy abandon.

Although it is risky to try to track down referential or autobiographical allusions in Rosselli's poetry, one cannot help thinking about the effect of electroshock administered in a modern hospital as the equivalent of the ancient martyrdom evoked here. "L'ingranaggio dei / pochi," this mysterious thing which is the cause of dis-order and dis-honor, but also of happiness and sleep, may then refer to the machine used to administer electroshock - electroshock being a privilege granted only to few. But the poem, like a perverse image-producing machine, at this point shifts gears and confronts us with another agony. (Doubling in an estranging form is a key device in Rosselli). As in a postmodern pastiche, the body of a dying dragon is juxtaposed metonymically to the martyred body on its deathbed: "Vicino al capezzale moriva un drago." The dragon in its agony projects us into the realm of fairy-tales or, keeping to the code of Christian iconography, evokes Saint George slaying the dragon, as in Carpaccio's famous painting at the Scuola di San Giorgio. The lower left foreground of that painting is taken up by the disturbing sight of the scattered limbs of a young woman the dragon has torn to pieces, miraculously leaving intact, however, her beautiful head and torso. As in the first two lines of Rosselli's poem, here too there is a striking contrast between the dis-order and dis-honor of this violated feminine figure, torn apart and dismembered, and the peaceful tranquillity of her closed eyes and delicate feminine breasts, as if she, too, were happily sleeping in her agony. But the rest of the line immediately dispells the somewhat perverse beauty evoked by this bit of necrophiliac voyeurism by plunging us - again with a sudden shift of gears and a swift change of register into the prosaic: "Moriva un drago, salumiere con i suoi salumi, le / sue code che pendevano molto puzzolenti." The phallic tension of the dragon (which Carpaccio emphasizes in his depiction of the monster's duel with Saint George and his spear, two phallic powers confronting one another) is comically deflated. Not only is the heroic struggle reduced to the vulgar buying and selling of meat but - were there any room for equivocation - the poem tells us exactly how rotten this activity is, how much it stinks. What is bought and sold in the symbolic economy of patriarchy is always and still the body of women. As soon as it is defeated, however, deprived of its phallic tension, "deflated," the body of the dying dragon becomes feminized, one and the same with the scattered limbs of the victims. Carpaccio's other painting, "San Giorgio vittorioso sul drago," depicts the 
dragon thus reduced, lying harmless on the ground with his neck in a leash held in the saint's left hand, while the right hand, holding a sword, is about to decapitate, i.e. castrate, him, and thus (according to the patriarchal logic by which the female is only a castrated male) "feminize" him. The dragon becomes feminized as one of those "monsters," like the Sphinx or Medusa, who are only obstacles on the male hero's path to manhood. ${ }^{26}$ This feminization in death redeems the dragon in the logic of the poem: "puzzolenti ma delicate nel loro odorare insieme." The second corpse in the lower foreground of Carpaccio's painting — that of a young man, also dismembered and strangely peaceful — is also delicate and effeminate: a double of the young girl, as if in death feminity prevailed over masculinity, or as if there were something connatural between feminity and death - a myth which the Antigone story in many ways seems to confirm.

The "delicate" smell of rotting flesh, the feminine agony, martyrdom, dishonor and dis-order of the opening lines are all geared towards the evocation of Antigone. Agony-Antigone: the assonance is all the more powerful in English. Even the duel alluded to through the image of the dragon points to Antigone. It is the duel between Polyneices and Eteocles, and their reciprocal killing, that leads Sophocles' Antigone to her own confrontation with Creon. Like the duel of Saint George and the dragon, Antigone's duel with Creon takes place amidst the smell of rotting flesh, for Antigone refuses to leave Polyneices's body unburied. In Rosselli's poem, whose body is Antigone called to bury?

As Rossana Rossanda has pointed out, of the many interpretations of the Antigone story (those by Hegel, Kierkegard, Hölderlin and Brecht are among the best known), none highlights or problematizes the fact that Antigone is a woman. ${ }^{27}$ All see in the story a paradigm of conflict in which the feminine plays only a subsidiary role. Or, when femaleness is highlighted (as with Hegel), it is in terms of the most traditional patriarchal vision of "women's roles." In Hegel's Phenomenology of Mind, the conflict between Antigone and Creon is one between the knowledge of oneself acquired within and through the family, and the superior, broader knowledge acquired as part of the multi-relational system of the state: as a woman Antigone "stands for" the family and the home. ${ }^{28}$ For Kierkegaard, Antigone's femaleness corresponds to another gender stereotype: she is the figure of a dangerous seduction by the deepest and most ambiguous secret hidden in her being (her knowledge of Oedipus's true predicament). Lacan, influenced by both Hegel and Kierkegaard, subordinates Antigone's femaleness entirely to the male plot of psychoanalysis; she is the incarnation of desire in its "pure" state (that is, in essence, male desire), the desire for the other as desire of the forbidden, the (m)other. Thus there is no real difference between Antigone and Hamlet. Sophocles's tragedy, Lacan argues, "presents man [sic] to us and interrogates him on the path of solitude." 29

Because her revision of the Antigone story is by a woman poet speaking in the first person, Rosselli's is neither as phallocentric as those of her male prede- 
cessors, nor does it gloss over Antigone's status as a woman. The first stanza frames the apparition of Antigone by evoking the martyrdom and agony of an unambiguously female-gendered speaking subject. The poem, while not espousing a male-centered system of signification, does not try to do away with it either. Rather, it mimics and parodies it by alluding to the death of the dragon and its stinking tails (and tales, for it is in these tales - such as the Carpaccio cycle of Saint George and the Dragon - that the commerce, death and dismemberment of women's bodies is represented again and again).

I said that Antigone "appears" in Rosselli's poem, but this is not altogether correct. Rather, she is evoked, or invoked: "se essa fosse venuta col suo gradito grido / d'allarme." "If only she had come." Antigone is elsewhere, not here. Unlike her male predecessors, who thought they could represent Antigone, speak for her, make her reappear on the stage of their texts in her truer being, Rosselli makes no such claims. She even deprives the name of the capital "A," the first letter that marks the proper name. "E se l'antigone che vegliava silenziosa . ..." Why this diminution to the lower case? The "real" Antigone (if this term may be adopted for a literary character), belongs, for one, in Sophocles's text, nor can it be re-presented except as a pale simulacrum or as another (in which case the proper name is a misappropriation). This Antigone, then (Rosselli's), is but one of many simulacra of the original; she is only an "antigone," as if the name had to be changed into a common noun. Indeed, nothing is proper to Antigone. She has through the ages been expropriated of everything, she has become common property, used differently - albeit always within the same masculine economy - with each successive rewriting. The conversion of the name to the lower case denounces - even as it unavoidably partakes in it - the violence of writing against woman, the turning of woman into an object of representational exchange within the patriarchal symbolic.

While not implying that hers is the true Antigone, Rosselli does assign to Antigone a place, a position. "E se l'antigone che vegliava silenziosa, molto silenziosa / ai miei poderi i miei prodotti disordinati, disadorni / di gloria, se essa fosse venuta col suo gradito grido / d'allarme, io morivo, molto silenziosa allarme." Antigone is elsewhere, in a place other than the scene of the poet's agony, keeping watch over something that belongs to the poet, the products of her labor ("i miei prodotti"). A number of connotations interweave here by virtue of the vocabulary and the associations that Antigone's figure calls to mind. First, the poet's "products" cannot but be her texts. Antigone, then, is keeping watch over the agonizing poet's poems. These are associated with the earth, and with the products of the earth, through the use of the word "poderi," which also, antithetically, evokes "poteri," the power of writing. This association of poems with the earth reminds us that Antigone's rite of burial is indeed, as Hegel remarked, a literal re-enclosure of her brother in the womb of the feminine earth, and echoes Cavarero's reading of the story of Demeter and Persephone, in which the feminine earth witholds her products (buried within her body) in protest 
against the masculine violation of her daughter's body. Because Antigone watches over them, these poem-products are implicitly linked to human remains, the remains of her brother Polyneices which are also "disordinati, disadorni / di gloria," for they lack the glory and dignity of a proper burial, and are exposed to vultures and dogs. (Sophocles's Antigone, in her mercy, has covered them with a thin veil of dust in defiance of Creon's orders). The dyad "disordinati, disadorni di gloria" also echoes the paired "Disonorata, disordinata" from the second line of the poem, linking the poem-products of the second stanza to the agonizing feminine body of the incipit. Body and texts are coterminous. Both are disordered, and dis-honored; both share the stigma of the prefix "dis," its expressing privation, dispersion and separation. But the texts differ from the body in having the privilege of Antigone's silent watch. They are dead and (almost) buried, mercifully covered with a thin veil of dust - and rendered invisible. It is precisely that privilege, the honor of being - like her poems - mourned by Antigone, which the poet invokes: "se essa fosse venuta col suo gradito grido / d'allarme, io morivo, molto silenziosa allarme." In Sophocles's text, Antigone sends out her cry of alarm when, on returning to her brother's burial site, she finds that he has been left unburied. Were Antigone's cry to be heard again it would mean that the poet, like her poems, would be free to die (to fulfill the bliss promised by her "happy" agony) with the knowledge that her body would be buried with the poems, and return to be one with them.

What is the meaning of this wish-for-a-burial, and in what sense are the poems already buried? Is it simply a death-wish, a "feminine" self-erasure in the face of patriarchal violence evoked in the first stanza? Antigone's centrality as the rebellious heroine who defies the laws of the city and of patriarchy - seems to argue against this, although her predicament remains highly ambiguous in Sophocles's play, for she kills herself by hanging (like her mother Jocasta) in the cave-tomb where Creon has ordered that she be buried alive, and in dying she calls into question all she has done. To answer these questions we must look at another reading of the Antigone myth.

Although deeply influenced by both Hegel and Lacan - hers is indeed a gloss of Hegel's interpretation of the myth, and it pursues the Lacanian question of desire, although in the direction of an exploration of female desire - Luce Irigaray's reading of Antigone in Speculum: De l'autre femme, centers on the question of Antigone's femininity and its ambiguous status in Sophocles's play. For while the "pure" relationship between brother and sister is idealized by Hegel as a relationship of sameness of blood without desire and therefore without violence, "this moment is mythical, of course, and the Hegelian dream [. . . is already the effect of a dialectic produced by the discourse of patriarchy. It is a consoling fancy, a truce in the struggle between uneven foes, a denial of the guilt already weighing heavily upon the development of the subject; it is the delusion of a bisexuality assured for each in the connection and passage, one into the other, of each sex (217). In Sophocles, however, "things are not yet that clear," 
for his work "marks the historical bridge between matriarchy and patriarchy [and] no decision has yet been made about what has more value" (217). Antigone's defiance of Creon is a rejection of the roles that patriarchy, at that particular stage of development in Greek civilization, imposes on woman. Refusing to be wife or mother, Antigone chooses to die a virgin. For Irigaray, the allegiance Antigone pledges to "another" law, the unwritten law (as opposed to the written ones of the city of men) of the "gods below," who uphold the sacredness of blood ties, is a form of transgressive desire: "Better to die than to refuse service to the divine law and to the attraction she feels for the gods below. There her jouissance finds easier recognition, no doubt, since her allegiance to them frees her from the inventions of men. She defies them all by/in her relationship to Hades. In her nocturnal passion she acts with a perversity which has nothing in common with the wretched crimes that men stoop to in their love for money" (218).

Antigone's nocturnal passion, argues Irrigaray, isolates her, makes her an outcast, places her outside of patriarchy and condemns her to annihilation: "Without friends, without husband, without tears, she is led along that forgotten path and there is walled up alive in a hole in the rock, shut off forever from the light of the sun. Alone in her crypt, her cave, her den, her womb, she is given just enough food by those who hold power to ensure that the city is not soiled and shamed by her decay" (218). But this path to self-destruction is also, ambiguously, a path back to the mother, and to all that patriarchy has tried to suppress: "By killing herself [does Antigone] anticipate the decree of death formulated by those in power? Does she duplicate it? Has she given in? Or is she still in revolt? She repeats, in any case, upon herself the murderous, but not bloody, deed of her mother. Whatever her current arguments with the laws of the city may have been, another law is still drawing her along her path: identification with her mother" (219). This path back to the mother marks the deadly uncertainty of a woman who, although rejecting the laws of patriarchy, cannot find a role or place for herself outside its violent economy. For what the mother is can no longer be grasped outside of the patriarchal order, even though for Sophocles this order is far from being fully in place, nor is it unambiguously positive (as it is for Hegel). For Irigaray, the fact that both Antigone and Polyneices have "doubles" in the play indicates that "this is still a transition in which the extremes - which will later be defined as being more masculine or more feminine: i.e. Eteocles and Ismene - seem almost like caricatures" (217). Unlike her tearful and submissive sister Ismene, Antigone never "becomes a woman" by the logic of Creon's patriarchy (indeed he fears that she might usurp his manhood), but "she is not as masculine as she might seem if seen from an exclusively phallic viewpoint - for it is tenderness and pity that have motivated her" (219). For Irigaray it is clear that Antigone "is a captive of a desire whose path has reached a dead end, has never been blazed" (219). ${ }^{30}$

A thorough unpacking of the allegorical logic of Rosselli's poem leads to a 
similarly oxymoronic reading. As in Irigaray, the question of the relationship between patriarchal violence and feminine desire or jouissance is central. The woman poet in agony who faces her own extinction with a sense of jouissance is, like Irigaray's Antigone, rejecting the violent logic of patriarchy. With their extravagant, obscure imagery and semantic opaqueness, Rosselli's poems place themselves on the margins of the symbolic and of "communication." They are, like Antigone herself, en-crypted, buried in the underground of writing. Although inscribed in an economy of writing which inevitably belongs to the patriarchal culture of mid-twentieth-century society, Rosselli's poems denounce this economy of writing as a betrayal. Her poems are, like the remains of Antigone's brother Polyneices, "disadorni di gloria," because they shy away from the monumentality of more ambitious poetic endeavours. They run counter to the tradition of the text as testament and monument. Rosselli's Antigone poem may be seen as a response to Foscolo's "I sepolcri," the greatest poem in the Italian tradition where the notions of literary testament and funerary monument are explicitly linked to the author's desire to find glory and eternal life through his writing. By placing Antigone in the role of silent guardian to her poems, Rosselli implicitly wishes that they might be un-written, be allowed, like Polyneices's remains, to decay and disintegrate without being seen and preyed upon.

This is, of course, impossible. Although (like her) Rosselli's poems denounce the violence of the Law and of the symbolic, and although (like Antigone) they pursue a different path (dictated by unwritten laws, which do not participate in the violent economy of patriarchal writing), there is no writing - except in madness - outside the symbolic, and writing exposes the text to the violence of interpretation. The desire that speaks in the poem, therefore, a desire that body and text be coterminous, and that both be mercifully buried by Antigone, remains "a desire whose path has reached a dead end, has never been ablaze." There is no indication, contrary to Irigaray's reading of Antigone's desire, and to Muraro's and Copioli's metaphysical impulse, that a return to the mother as origin and authentic locus of being might provide the symbolic framework for a new feminist politics. Ultimately what the poem expresses, through the oxymoron of the "silent alarm" ("silenzioso allarme") is the contradictory wish both to be dead and silent, like Antigone, and to retain, like Antigone, the disruptive power of a cry of denunciation and rebellion against the violence of patriarchy.

The oxymoronic logic of Rosselli's deconstruction of the Antigone myth holds little promise of a radical change in the structures of the symbolic and of patriarchy. Like Antigone herself, Rosselli increasingly refuses any compromise with politics, or with writing itself. Silence surrounds her verses, and constantly threatens to obliterate them. Her approach, therefore, differs substantially from the more positive logic of the poets and thinkers associated with the Diotima group. While Rosselli's dark vision has the appeal of an uncompromising formal and epistemic rigour, and her highly "writerly" texts generate their own, difficult esthetic pleasure, its political impact is bound to be extremely circumscribed. It 
is, to use Adorno's phrase, the impact of a "negative dialectics." The esthetic rigour and strange beauty of her poetry are a critique of the intolerability of the real, and a metaphor of how things should be otherwise. But for all its denunciation of the violence of writing, this poetry does not attempt to imagine a way of mediating between writing and other spheres of experience. It remains in writing, and in a way this is the principal reason for its deconstructionist rigour and beauty. Such rigour and beauty are - like the admirable stubborness of Antigone - politically suspect to other women. Irigaray herself, in her 1984 Ethique de la différence sexuelle, states the need to go beyond Antigone (and the deconstructionist version of her parable she had given in Speculum) to embrace the project of a new feminine subjectivity and ethics. In her commentary on this further revision of the Antigone story, Gloria Zanardo - a member of the Italian feminist group "Il filo di Arianna," which is closely associated with the Diotima group - concludes on a note indicating how these women see the entire project of mythic revisionism from a philosophical and political perspective: "Lo sforzo di Antigone risulta inutile e destinato al fallimento, come ha fallito Antigone stessa, se le donne non contrappongono alla legge della città una loro legge .... . Il mondo comune delle donne articola una struttura etica affinché le donne si riapproprino della vita e dell'energia che a loro appartiene, piuttosto che spenderla per dare vita a un morto" (90-91). ${ }^{31}$

Whatever one thinks of the advantages and disadvantages of the various strategies of mythic revisionism I have discussed, as a whole (and despite their different formal, epistemic, and political approaches), they represent one of the most compelling ways through which Italian women writers - poets, philosophers, critics - are calling into question the ideological underpinnings of a male-centered tradition while at the same time opening up a space for a feminine symbolic, a symbolic where the feminine is no longer always subordinate, secondary or negative, but takes on legitimacy and significance in its own right.

\section{University of California, Los Angeles}

\section{NOTES}

1 Some of the most convincing discussions of this subject are de Lauretis's "The Technology of Gender," and Judith Butler's Gender Trouble.

2 Luigi Baldacci, introduction to Spaziani, Poesie 9 and passim. All translations from the Italian in the text are mine, unless otherwise noted.

3 See for example Antonio Porta's review of Patrizia Valduga's Medicamenta (86).

4 Luce Irigaray and Hélène Cixous are traditionally associated with the notion of "écriture féminine." Irigaray is actually suspicious of the notion of writing and prefers to speak of a "parler femme," a writing which has the fluidity and (in)formality of speech. See especially her "Quand nos lévres se parlent." In Speculum de l'autre femme, she emphasizes the need for women authors' self-representation of their own sexed body and subjectivity, or what she calls "a morpho-logic appropriated from the body." The classic text by Cixous on feminine writing is "Le Rire de la Méduse." See also Conley, Shiach, and Jones. For critiques, see Jacobus and Felski. For a broader, rigorous and fascinating study 
on language and sexual difference using a socio-linguistic and semiological approach, see Violi.

5 This lack is being remedied slowly by studies such as Cixous's on Clarice Lispector (see for example "Coming to Writing"), and Breaking the Sequence, edited by Friedman and Fuchs. Suleiman's Subversive Intent is also a pioneering work in the study of women and the avant-garde.

6 Cavarero's notion of the symbolic order is loosely based on the Lacanian notion of the Symbolic, via the mediation of Irigaray. See also Muraro 111.

7 A founding member, along with Muraro, of the Italian feminist group of philosophers called "Diotima," Cavarero partakes in a specifically Italian tendency - within feminism - to attribute to sexual difference a fundamental role, which many Anglo-American critics have called "essentialist." On the virtues and vices of essentialism, see de Lauretis, "Essentialism."

8 See Alicia Ostriker, "The Thieves of Language." This essay - in many ways a pioneering work in feminist criticism - inspired many of my own thoughts. I owe an earlier debt to Harold Bloom on revisionism in poetry: "A poem is not writing, but rewriting," Bloom says (3). The notion of writing (and reading) by women as "re-vision" originates with Adrienne Rich's "When We Dead Awaken." On the revision of classical myths by modern American women poets, see Blau Du Plessis 105-41.

9 Alta, "euridice," quoted in Ostriker 318.

10 See for example Sergio Solmi's claims, cited in Petronio 896-97.

11 Evidence of this continuity may be found in the "Congedo" to Luigi Ballerini's recent Che figurato muore: the loss of Eurydice becomes an allegory of the desirable, even necessary loss of literal referentiality in poetic discourse; in other words, the beloved has to be dead for the poetry to be good.

12 For two different revisionist rewritings of the myth that attribute to Eurydice an empowered role, see Copioli, "Euridice," in Furore (23), and Splendore, "Orfeo e Euridice" in Elena (41-43).

13 For an overview of Spaziani's work, see West.

14 Montale is of course rather a contemporary of Spaziani than a predecessor strictu sensu. Spaziani also happened to be, for a time, Montale's lover and the poetic beloved, under the name of "Volpe" of a number of Montale's poems.

15 Pascoli's poems "Il morticino," "L'agonia di una madre," "Colloquio" (all from Myricae) and "Mia madre" (from Canti di Castelvecchio), are cases in point.

16 "Variazioni sul tema di Penelope," cited in Cavarero 21.

17 Hannah Arendt points out in The Life of the Mind that "even the younger Heidegger of Sein und Zeit still treated the anticipation of death as the decisive experience through which man can attain an authentic self and be liberated from the inauthenticity of the They" (80-81). See also Blanchot.

18 One of the more dubious though appealing implications of Irigaray's theory is that women are somehow outside the rule of technology and its nihilistic results, and that women therefore constitute a reservoir of hope for the world's salvation.

19 Muraro is critical of post-structuralist modes of thought, and especially critical of feminist thinkers such as Joan Scott who think that postructuralist theory can fulfill the needs of feminist theory. Muraro also finds most modern critiques of metaphysics (she cites Derrida, Foucault and Vattimo) ineffectual.

20 Muraro specifies, citing Adrienne Rich, that when she refers to "the father" as the third member of the Oedipal triangle she is not talking about the actual father, nor about the father in a purely symbolic sense, but about the patriarchal power (45).

21 Muraro cites Irigaray's Sexes et parenté.

22 See Bürger, esp. 68-82, and see Luperini. 
23 See the volume of essays Anima Mundi.

24 By Niccolai, see "Harry's Bar Ballad" (1977) in Harry's Bar e altre poesie (137-38).

25 See Bürger 68-82.

26 See de Lauretis, Desire in Narrative 116-21.

27 See Rossanda 14. For a comprehensive account of the metamorphoses of Antigone, see Steiner. A few women have written about Antigone: George Eliot, Virginia Woolf, Margaret Drabble; see Joseph. The most notable Italian revision of the Antigone story by a woman is Liliana Cavani's 1970 film, I cannibali, where, however, Antigone's female identity is secondary to her role of political opposition.

28 See Rossanda 26, and Steiner 28-42. See also Derrida's critical gloss in Glas 108-14, which highlights the gender polarization in Hegel's interpretation.

29 Vol. 7 of Le Séminaire, L'éthique de la psychanalyse 328-29 and 331.

30 For a less nuanced feminist interpretation of the Antigone story, partly based on a reading of Irigaray, see Féral 2. For a critique, see Du Bois.

31 See also the section entitled "Antigone la custode del corpo" in Izzo, "Immagini."

\section{WORKS CITED}

Arendt, Hannah. The Life of the Mind: Thinking. New York: Harcourt Brace Jovanovich, 1971.

Ballerini, Luigi. Che figurato muore. Milano: All'insegna del pesce d'oro, 1988.

Benjamin, Walter. The Origin of German Tragic Drama. London: NLB, 1977.

Bimbi, Franca, Laura Grasso, Marina Zancan, Gruppo di filosofia femminile "Diotima." Il filo di Arianna: Letture sulla differenza sessuale. Roma: Utopia, 1987.

Blanchot, Maurice. The Gaze of Orpheus and Other Literary Essays. Barrytown, NY: Stationhill, 1981

Blau Du Plessis, Rachel. Writing Beyond the Ending: Narrative Strategies of Twentieth-Century Women Writers. Bloomington: Indiana UP, 1985.

Bloom, Harold. Poetry and Repression: Revisionism from Blake to Stevens. New Haven: Yale UP, 1976.

Bürger, Peter. Theory of the Avant-Garde. Trad. Michael Shaw. Minneapolis: U of Minnesota P, 1984.

Butler, Judith. Gender Trouble: Feminism and the Subversion of Identity. New York: Routledge, 1990.

Campana, Dino. Canti Orfici e altre poesie. Milano: Garzanti, 1989.

Cavarero, Adriana. Nonostante Platone. Figure femminili nella filosofia antica. Roma: Editori Riuniti, 1991.

Cixous, Hélène. "Coming to Writing" and Other Essays. Ed. Deborah Jenson. Cambridge, Mass.: Harvard UP, 1991.

"Le Rire de la Meduse." Revised version in Marks and De Courtivroneds. New French Feminisms: An Anthology. 245-64. [Originally published in L'Arc (1975): 39-54.]

Conley, Verena Andermatt. "An Exchange with Hélène Cixous." In Hélène Cixous: Writing the Feminine. Lincoln, Nebraska: U of Nebraska P, 1984. 129-61.

Copioli, Rosita. Anima Mundi. Parma: Guanda, 1988.

. Furore delle rose. Parma: Guanda, 1989

"Per l'anniversario di Colombo, in Giamaica." Tuttestorie. Racconti, Letture,

Trame di Donne 3-4 (November 1991): 100.

de Lauretis, Teresa. Alice Doesn't: Feminism, Semiotics, Cinema. Bloomington: Indiana UP, 1984.

. "The Essence of the Triangle or, Taking Essentialism Seriously: Feminist Theory

in Italy, the U.S., and Britain." Differences 1.2 (1990): 3-37.

. "The Technology of Gender." Technologies of Gender. Bloomington: Indiana 
UP, 1987. 1-30.

de Man, Paul. "The Rhetoric of Temporality." Blindness and Insight. Essays in the Rhetoric of Contemporary Criticism. Minneapolis: U of Minnesota P, 1983. [Second edition, revised.]

Derrida, Jacques. Glas, Lincoln: U of Nebraska P, 1986.

Di Battista, Maria. "The Clandestine Fictions of Marguerite Duras." Friedman, Ellen G. and Miriam Fuchs. Breaking the Sequence: Women's Experimental Fiction. 284-97.

Du Bois, Page. "Antigone and the Feminist Critic." Genre 19.4 (1986): 371-82.

Felski, Rita. Beyond Feminist Esthetics: Feminist Literature and Social Change. Cambridge, Mass.: Harvard UP, 1989.

Féral, Josette. "Antigone or The Irony of the Tribe." Diacritics 8.3 (1978): 2-13.

Frabotta, Biancamaria, ed. Donne in poesia. Antologia della poesia femminile in Italia dal dopoguerra a oggi. Roma: Savelli, 1977.

Friedman, Ellen G. and Miriam Fuchs. Breaking the Sequence: Women's Experimental Fiction. Princeton: Princeton UP, 1989.

Gargani, Aldo. "La voce femminile." Alfabeta 64 (September 1984): 16.

Gauthier, Xavière. "Is There Such a Thing as Women's Writing?" Trad. Marilyn A. August. Marks, Elaine and Isabelle de Courtivron, eds. New French Feminisms: An Anthology. 161-64. [Trad. of "Existe-t-il une écriture féminine?", 1974.]

Hegel, G.W. The Phenomenology of Mind. Trad. J.B. Baille. New York: Harper Torchbooks, 1967.

Irigaray, Luce. "Quand nos lèvres se parlent" ("When Our Lips Speak Together"). Signs 6.1 (1980): 69-79.

. Speculum of the Oher Woman. Trad. Gillian C. Gill. Ithaca: Cornell UP, 1985.

Izzo, Francesca. "Il materno tra origine e storia." (Rev. of Luce Irigaray's Sexes et parenté). Reti 2 (1989): 23-26.

. "Immagini del soggetto moderno: Etica e soggettività." Reti 3-4 (1989): 304-06.

Jacobus, Mary. "The Question of Language: Men of Maxims in The Mill on the Floss." Writing and Sexual Difference. Ed. Elizabeth Abel. Brighton: Harvester, 1982. 37-52.

Jones, Ann Rosalind. "Inscribing Feminity: French Theories of the Feminine." Gayle Greene and Coppelia Kahn, eds, Making a Difference: Feminist Literary Criticism. London: Methuen, 1985. 80-112.

"Writing the Body: toward an Understanding of l'écriture féminine." Feminist Studies 7.2 (1981): 247-63.

Joseph, Gerhard. "The Antigone as a Cultural Touchstone: Matthew Arnold, Hegel, George Eliot, Virginia Woolf, and Margaret Drabble." PMLA 96 (1981): 22-35.

Kristeva, Julia. Revolution in Poetic Language. New York: Columbia UP, 1984.

Lacan, Jacques. "The Mirror-phase as Formative of the Function of the I." New Left Review 2.51 (1968): 71-77.

. Le Séminaire. Vol VII. L'éthique de la psychanalyse. Paris: Seuil, 1986.

Luperini, Romano. L'allegoria del moderno. Roma: Editori Riuniti, 1990.

Marks, Elaine, and Isabelle de Courtivron, eds. New French Feminisms: An Anthology. New York: Schocken Books, 1981.

The Milan Women's Bookstore Collective (Libreria delle donne di Milano). Sexual Difference: A Theory of Social Symbolic Practice. Bloomington, Indiana UP, 1990.

Muraro, Luisa. L'ordine simbolico della madre. Roma: Editori Riuniti, 1991.

Niccolai, Giulia. Harry's Bar e altre poesie 1969-1980. Milano: Feltrinelli, 1981.

Ostriker, Alicia. "The Thieves of Language: Women Poets and Revisionist Mythmaking." Elaine Showalter, ed. The New Feminist Criticism. New York: Pantheon Books, 1985. 314-38. [Originally published in Signs 8 (1981).]

Petronio, Giuseppe. L'attività letteraria in Italia. Florence: Palumbo, 1980.

Porta, Antonio. Rev. of Patrizia Valduga's Medicamenta. In $/ l$ corrietre della sera (26 september 1982). [Rprnt in $/ l$ progetto infinito. Roma: Edizioni Fondo Pier Paolo Pasolini, 1991. 85-86.] 
Quasimodo, Salvatore. La vita non è sogno. Milano: Mondadori, 1966. [Original ed. 1949.]

Rich, Adrienne. "When We Dead Awaken: Writing as Re-Vision." [1971] On Lies, Secrets, and Silence Selected Prose 1966-1978. New York: Norton, 1979.

Rose, Jaqueline. "Introduction" to Feminine Sexuality: Jacques Lacan and the Ecole Freudienne. New York: Norton, 1982.

Rossanda, Rossana. Introduction to Sofocle, Antigone. Trad. Luisa Biondetti. Milano: Feltrinelli, 1987. 7-58.

Rosselli, Amelia. Variazioni belliche. Milano: Garzanti, 1964.

Shiach, Morag. "Their 'symbolic' exists, it holds power - we, the sowers of disorder, know it only too well." Between Feminism and Psychoanalysis. Ed. Teresa Brennan. London: Routledge, 1989. 153-67.

Spaziani, Maria Luisa. Poesie. Introd. Luigi Baldacci. Milano: Mondadori, 1979.

Spivak, Gayatry. "Sex and History in The Prelude (1805): Books IX to XIII." Post-Structuralist Readings of English Poetry. Eds. Richard Machin and Christopher Norris. Cambridge: Cambridge UP, 1987. 193-226.

Splendore, Carmen. Elena, Ippolita e le altre. Palermo: Dharba, 1992.

Steiner, George. Antigones: How the Antigone Legend Has Endured in Western Literature, Art, and Thought. Oxford: Clarendon Press, 1986.

Suleiman, Susan. Subversive Intent. Gender, Politics, and the Avant-Garde. Cambridge, Mass.: Harvard UP, 1990.

Ungaretti, Giuseppe. Vita d' un uomo: Tutte le poesie. Milano: Mondadori, 1992.

Violi, Patrizia. L'infinito singolare. Considerazioni sulla differenza sessuale nel linguaggio. Milano: Essedue Edizioni, 1987.

West, Rebecca. "Maria Luisa Spaziani." Dictionary of Literary Biography. Ed. G. De Stasio. Forthcoming.

Zanardo, Gloria. "Lettura dell'Antigone di Sofocle in Etica della differenza sessuale." Bimbi, Grasso, Zancan, Gruppo di filosofia femminile Diotima. Il Filo di Arianna: Letture della differenza sessuale. Roma: Utopia, 1987. 